\title{
Plant Disease Epidemiology in the Twentieth Century A Picture by Means of Selected Controversies
}

The essence of science is to ask questions and to discuss possible answers. In the course of time, old questions may become irrelevant and old answers may prove to be incorrect. Science is alive as long as the discussion goes on. Controversy stirs discussion. In this paper on plant disease epidemiology in the twentieth century, I intend to discuss some selected controversies from three periods: before, during, and after J. E. Vanderplank.

\section{The pre-Vanderplankian Period}

The discussion during the nineteenth century was dominated by the feud between the autogenetists (autogenesis = generatio spontanea) and the pathogenetists, to borrow H. H. Whetzel's terminology (119). Summarizing briefly, the autogenetists claimed that fungus was the outcome of disease, whereas the pathogenetists said that fungus was the cause of disease. With a wink to Louis Pasteur (75) and Anton De Bary (20), phytopathologists (89) decided in favor of the pathogenetists and accepted Koch's "postulates" $(55,56)$ as a methodological tool to demonstrate the pathogenicity of an organism, viruses included (8).

Many textbooks from the early twentieth century avoided the controversy by using a terminology that is vague and evasive in our present eyes $(22,54,106,114)$, and I do not know when the postulates really came into use. Today, we try to distinguish clearly between cause and condition, hammering this difference into the heads of our students. We teach the convention that the pathogen is the cause of disease, but that the pathogen needs favorable conditions to do its work. Philosophically, the distinction between cause and condition is clear. In a given case, the distinction may be less obvious, especially when the shortterm desire for profit wins over the longterm wisdom of sustainability. We tend to ignore the idea that the greedy human may set the conditions for the pathogen to do

Dr. Zadoks is Professor Emeritus, Laboratory of Phytopathology, Wageningen University and Research Center, POB 8025, 6700 EE Wageningen, Netherlands;

E-mail: jczadoks@euronet.nl

Publication no. D-2001-0614-01F

(C) 2001 The American Phytopathological Society harm, for example, by shortening the crop rotation period so much that problems are solicited due to soilborne fungi and nematodes. In this case, the pathogen is the proximate (4) cause and man is the ultimate cause of disease, as pictorialized by the disease tetrahedron (127; Fig. 1). And in this case, the major fight of the nineteenth century is not yet concluded, today, in the twenty-first century.

Following, are three controversies from the early part of the twentieth century, the pre-Vanderplankian period. The first, on Eriksson's mycoplasma theory, remained inconsequential. The second, on Marshall Ward's bridging host theory, has led through improved methodology to unexpected vistas. The last, on epidemiological growth curves, is still ongoing.

Controversy one: mycoplasma. The Swede Jakob Eriksson (1848-1931; Fig. 2 ), the international leader of phytopathology in his time (31), created the concept of the formae speciales in cereal rusts $(2,32)$ and studied the overwintering of stripe rust (Puccinia striiformis) on wheat. To explain the apparent disappearance of rust during winter, he hypothesized that the rust mycelium residing in the leaves of field-grown winter wheat would lose its individuality by merging with the cytoplasma in the host-cell to form a chimeric unit, which he called a "mycoplasm." Mycoplasm also explained the supposed seed transmission of stripe rust $(24,26)$. At the time, the concept of mycoplasma was already known in medicine. Eriksson (25) wrote that he actually had seen mycoplasms under the microscope.

The Brit Harry Marshall Ward (Fig. 3), famous for having solved (113) the problem of the coffee leaf rust (Hemileia vastatrix) in Ceylon (=Sri Lanka), accused Eriksson of poor microscopy $(116,118)$. Eriksson (27) had to admit that the mycoplasms he had seen were in fact haustoria. However, a petulant Eriksson did not give up, changed his argument $(28,29)$, and fiercely defended his mycoplasm theory. He underpinned his views with fresh evidence from another pathosystem (30), rust on hollyhock (Puccinia malvacearum), evidence that was circumstantial at best. As far as I know, Eriksson chose to ignore the deadly comment by Biffen (7) on the mycoplasm theory as an explanation for seed transmission of stripe rust, a comment based on the just-detected mode of inheriting resistance against stripe rust. Klebahn (54) in 1912 dryly stated that the theory did not meet with much support ("kein Beifall"), and Brierley (9) in 1930 even

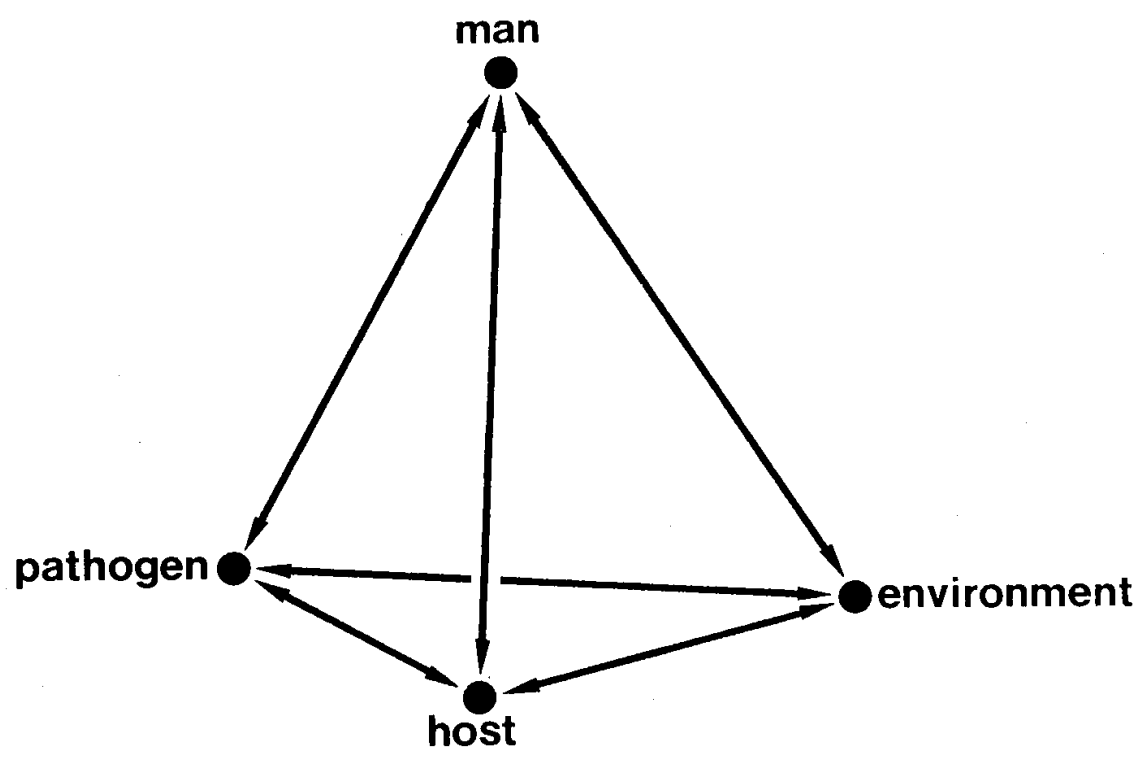

Fig. 1. The disease tetrahedron, dominated by man the farmer, manager, administrator. The horizontal plane or base represents the classical disease triangle. (127, printed with permission) 
used the word "ludicrous." Fifty years later, simple experimental methods, already available to Eriksson in the 1890s, showed once more that the mycoplasm theory was superfluous (121). Numerous attempts at demonstrating seed transmission of stripe rust failed as miserably as those with stem rust (47).

Even great men may err. Eriksson was wrong, but we do not deny the existence of mycoplasmalike organisms as plant pathogens, demonstrated convincingly in later years. Here, I pay tribute to Jakob Eriksson who, mistaken in his mycoplasma theory,

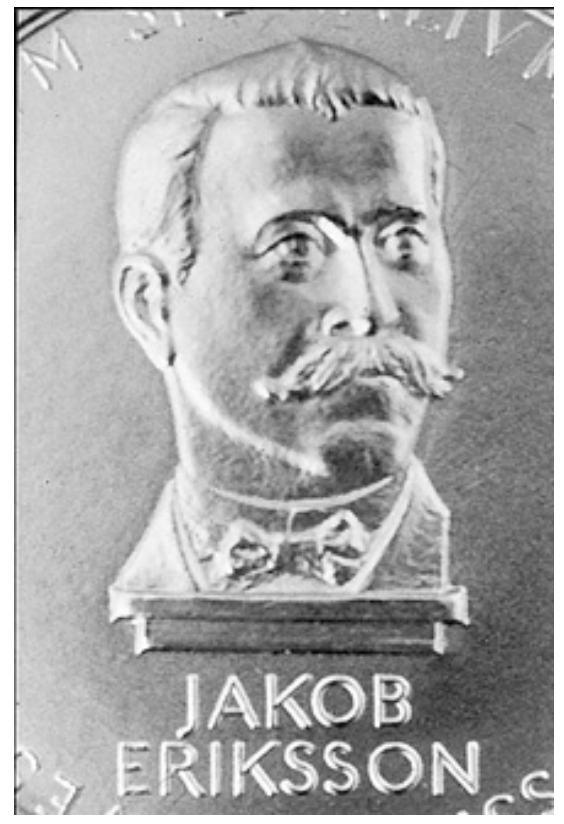

Fig. 2. Professor Eriksson, Sweden. Portrait from the Eriksson Gold Medal for Excellence in Phytopathology. Picture kindly provided by the 1993 Laureate, Professor Ariena van Bruggen.

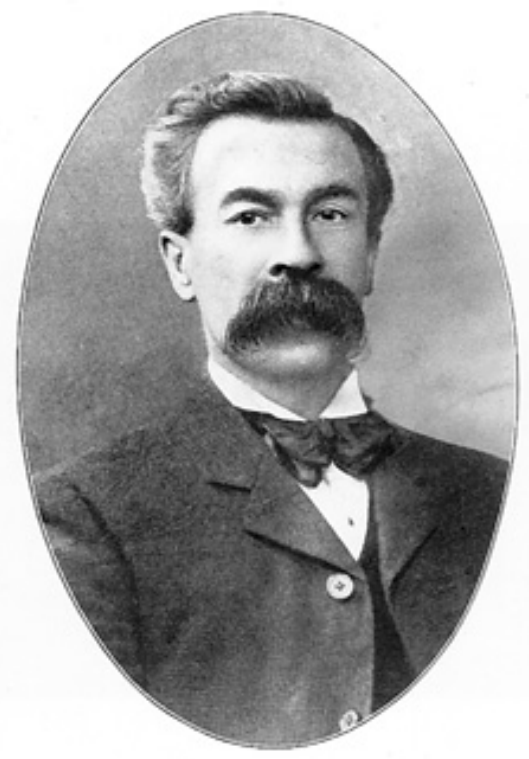

Fig. 3. Professor Henry Marshall Ward (39). was nonetheless a great phytopathologist, a real internationalist, and a typical forerunner of epidemiology.

Controversy two: bridging hosts. Harry Marshall Ward (1854-1906) studied the rust of brome grasses, Puccinia dispersa (Erikss.), and formulated the "bridgeing host" theory (117). In his words, a "bridgeing species" allows "the passage of the fungus from species of one circle of alliance to those of another, in spite of the fact that it is usually closely adapted to species of one section of the genus only." In other words, he assumed that a rust species found on a first grass species could pass over a second grass species to become infectious to a third one, not related to the first. The second host species he dubbed "bridgeing host." Ward provided arguments from his own experiments and quoted guest workers studying rust and mildew of bromes (Bromus spp.).

Ward (115) developed a kind of axenic single-plant culture. He used spore batches and he did not mention single-spore or single-pustule cultures. (Ward's confusion is quite understandable because differential interactions between pathogen and host phenotypes at levels from the forma specialis to the pathotype can be very complicated in natural situations [2].) Brooks (10) pointed out that in Ward's time, "the importance of maintaining the purity of the physiologic races under investigation was not realized..." and he concluded that "The existence of 'bridging hosts' in connection with other fungi has not been substantiated." The experimental results could not be replicated by others and could be ascribed as well to impurity of the inoculum used. The bridging host theory was refuted by E. C. Stakman et al. (92).

The link between Marshall Ward and Stakman is E. M. Freeman from the University of Minnesota, who spent the spring and early summer of 1892 in Cambridge. (Ward apparently misquoted Freeman's initials in some of his papers.) Freeman published on rusts of bromes (38), and he wrote a memorial to Ward (39). While head of the Division of Plant Pathology on the St. Paul campus, Freeman hired E. C. Stakman as an instructor in plant pathology. Later, he became Stakman's Ph.D. supervisor (17). Stakman obviously liked methodological skirmishes, but curiously the first description of single-spore and single-pustule isolation is not attributed to Stakman but to E. B. Mains $(62,77)$. Stakman's work, in my opinion, led to the nearelimination of stem rust (Puccinia graminis) of wheat from the United States and many other parts of the world (17).

Controversy three: epidemiological growth curves. The never-ending discussion about growth curves is a very polite one, and the controversy is under the surface rather than explicit. The exponential growth of a population was first described by the Dutch microbiologist Anthonie van Leeuwenhoek in 1716 (23). A good second was the French physicist Réaumur, in about 1734. In 1798, the English reverend Malthus (63) developed his gloomy view on mankind based on its supposed exponential growth as opposed to the putative arithmetic increase of food resources. In 1838, the Belgian mathematician Verhulst (105) developed the logistic equation to describe the growth of human populations, an equation reinvented

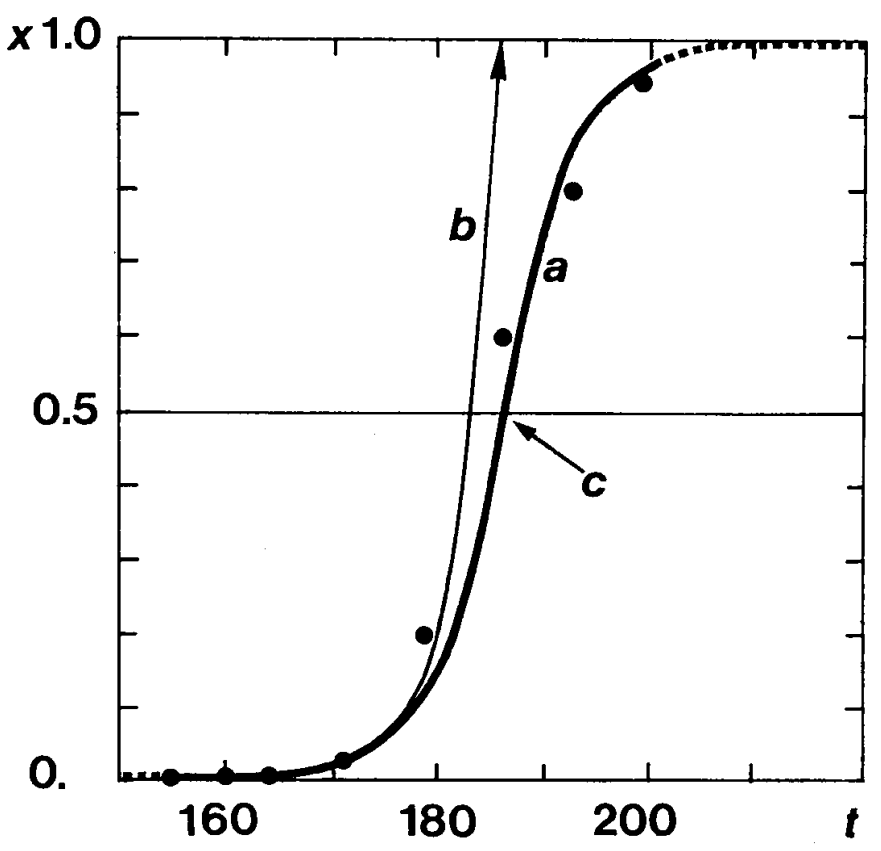

Fig. 4. Example of logistic growth of Puccinia striiformis in a wheat field. Horizontal: time in days. Dots are observation points in time with severity $x(0 \leq x \leq 1.0)$. a. Sshaped logistic curve. b. Exponential curve fitting the early data. c. $50 \%$ severity point. (127, printed with permission) 
by the Americans Pearl and Read in 1920 (76). In 1960, Vanderplank (99) lighted the candle using the logistic equation as a tool in comparative epidemiological studies (100,121; Fig. 4).

In addition to the classical logistic equation, with one parameter only, a family of equations was created describing asymmetric S-shaped curves $(12,42)$. Disease progress curves attained great descriptive precision, with coefficients of correlation between observed and calculated values exceeding 99\%. Unfortunately, the explanatory value of these equations decreases with increasing descriptive precision. Hence, the usefulness of such precision is questionable. To quote a completely arbitrary example: "The Gompertz model gave the best statistical fit for the progression of disease incidence over time" (96), which I consider an empty statement. In methodological terms, the extra parameters needed to obtain the precision lack "empirical references." Descriptive over-perfection does not necessarily provide acceptable predictions.

In my opinion, the steady progress in calculation capacity has not contributed much to practical objectives based on disease progress curves such as spray warnings and loss prediction. In fact, prediction and spray warning using the simplest exponential equation may be perfectly adequate (123). The controversy, buried under peer admiration and editorial perfectionism, is worth a frank and open discussion.

\section{Vanderplank and the Birth of Plant Disease Epidemiology}

In my view, plant disease epidemiology gained its status as a separate discipline in 1963, due to two near-simultaneous events. One was the first international meeting of some 40 plant disease epidemiologists in

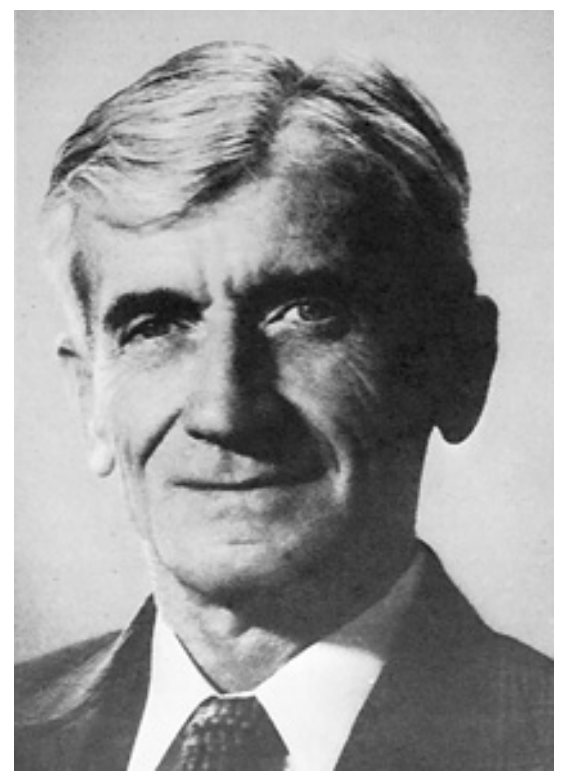

Fig. 5. J. E. Vanderplank. (128, printed with permission)
Pau, France. (The meeting was strictly informal, and no proceedings appeared. Pau started a sequence of similar informal meetings on plant disease epidemiology, including those at Wageningen [Netherlands, 1970], Raleigh [United States, about 1979], State College [United States, about 1982], Jerusalem [Israel, 1986], Giessen [Germany, 1990], Papendal [Netherlands, 1994], and Ouro Preto [Brazil, 2001].) The meeting was organized by Rick D. Schein from the United States and Jim Hirst from the United Kingdom as a corollary to another congress (43). The second event was the appearance of Vanderplank's famous book, Plant Diseases: Epidemiology and Control (100). Vanderplank (Fig. 5) was present at Pau, smiled and kept quiet, as he did not want to anticipate what was already in press. (Vanderplank told me that his British-born ancestors were of Flemish-Belgian descent and wrote their name as Vanderplank, in one word, as is still customary in Belgium. In official life he used the Dutch manner of writing, van der Plank, which was more congenial to the Afrikaners, the South Africans of Dutch descent.)

A body of knowledge obtains the status of discipline only when it is consistent in description and comparison and when it is applicable in extrapolation and prediction. Consistency cannot be measured, but it can be experienced. Under similar conditions, similar causes should lead to similar effects. Epidemiology suffers from the heterogeneity of its subject: so many crops, pathogens, weather types, and cultivation methods. Nonetheless, epidemiology is gaining consistency by the application of a limited vocabulary, the systematic use of generally accepted statistics to design experiments and test their results, and the assiduous application of mathematics. The feeling of commonality in a plethora of epidemiological problems and the need for a common language became apparent at the meeting in Pau, 1963. Vanderplank's 1963 book provided just that: a common language, consistency, and applicability.

Of course, Vanderplank used an already existing body of knowledge built by many outstanding scientists $(13,126)$. But these scientists did not consider themselves epidemiologists, even when they were consciously engaged in epidemiological research. Their work, outstanding in their time, lacks the coherence, predictability, and general applicability of a discipline per se. These persons, among whom were the already-mentioned Marshall Ward and Eriksson, I designate as forerunners. I respect and admire them, but I do not call them epidemiologists.

\section{Vanderplankian Controversies}

Vanderplank's innovations sent shockwaves of surprise and commotion through the scientific world. He created and liked controversy, but he avoided discussion and he pressed his opponents to prove him wrong by experimentation. I will mention three controversies created by Vanderplank.

Controversy one: horizontal resistance. In a brilliant combination of epidemiology and genetics, Vanderplank (100) postulated his antithesis of vertical and horizontal resistance (Fig. 6). I witnessed vehement and endless discussions between plant breeders and plant pathologists on the pros and cons of horizontal resistance (68). (Nelson's challenge of Vanderplank's definition of horizontal resistance was based on an omission in the 1963 book by Vanderplank, where he implied but did not state explicitly that the two genetic systems underlying vertical and horizontal resistance, respectively, were supposed to coexist in one genotype.) In the beginning, Vanderplank met with fierce opposition from the breeders and with enthusiastic support by a small band of pathologists. At meetings, the converted preached to the believers (vide 59), generating a wealth of new ideas aimed at damping down the "boom-and-bust cycles" of epidemics. In the end, after about 25 years, the storm subsided and Vanderplank's ideas on "vertical" and "non-vertical" resistance became generally accepted (vide 48).

The interesting point is that Vanderplank was fundamentally wrong with his horizontal resistance. The existence of horizontal resistance cannot be proven, as follows from its definition (Sidebar 1). (The argument is in the observed reaction of known isolates; a next, not-yet-known isolate may refute the idea of horizontality by causing a very different reaction.) Detailed measurements did not confirm the posit of horizontal resistance $(67,121)$. What remained were concepts such as "intermediate resistance" (122) and a special version thereof, "partial resistance" $(72,73)$. In the vein of scientific rebellion, Parlevliet and Zadoks (74) proposed a model with differential interaction between host and parasite genotypes at the microlevel.

At the instigation of Raoul Robinson, the Food and Agriculture Organization (FAO) of the United Nations, Department of Plant Protection, initiated research on horizontal resistance in developing countries (83), largely financed by the Dutch government. Results, laid down in a set of $\mathrm{Ph} . \mathrm{D}$. theses, demonstrated that partial resistance provided an operational principle. The concept of partial resistance was further operationalized by another set of Ph.D. thesis researches (vide 48). The outcome will improve sustainability of resistance, without booms and busts and thus with less recourse to pesticides.

Controversy two: the mathematical point as the epidemiological universe. Mathematics in plant disease epidemiology were introduced primarily by Vanderplank (99). The light shone brightly when Vanderplank (100: equation 8.3, page 100) 
advocated his famous equation

$$
d x / d t=R_{c} \cdot\left(x_{t-p}-x_{t-i-p}\right) \cdot\left(1-x_{t}\right)
$$

where $x=$ fraction of diseased plant material, $R_{c}=$ corrected basic infection rate (Sidebar 1), $p=$ latent period, $i=$ infectious period, and $t=$ time. This equation is intellectually satisfactory, and it has a strong explicative value; it is a great teaching aid. Nonetheless, the equation is fundamentally wrong. It represents the growth of an epidemic in time, but the spatial dimension of the epidemic is the mathematical point, the nonspace. However, an epidemic has a spatial dimension, which affects the shape of the epidemic growth curve in time $(49,51)$

Of course, Vanderplank was aware of the spatial aspects of epidemics. He discussed them extensively, introducing the term "horizon of infection" (98). In his books $(100,102,103)$, he tended to discuss time and space separately. In a paper specifically devoted to "spread of plant pathogens in space and time" (101), he did not find an acceptable solution for the spacetime problem, i.e., combining disease progress in time and in two-dimensional space by a single equation. Numerical mathematics showed a way out, in this case dynamic simulation using a digital computer $(51,53)$. Analytical mathematics $(21,49,50$, $125)$ brought the final solution. One outcome was a theory on focus formation at the micro-, meso-, and continental levels (Fig. 7). Continued integration of epidemic processes in time and space is intellectually demanding, and the supporting experimentation is costly, but the rewards will be great (124).

Controversy three: numerical mathematics. The generation of phytopathologists before Vanderplank largely ignored the potential of analytical mathematics (vide quotation in 124). Vanderplank was a good mathematician and elaborated many epidemiological questions by the application of analytical mathematics. He did not yet appreciate the potential of numerical mathematics, as applied in dynamic simulation. He criticized the results of the famous simulators EPIDEM and EPIMAY $(109,110)$ severely, although not unjustly (103: ch. 4.7).

Obviously, Vanderplank did not like dynamic simulation, as he told me personally. In his aversion to simulation, he was a typical representative of his generation. "Computers and plant pathology? Can't be done!" exclaimed a respectable colleague (who had never seen a computer) in 1976, when I proposed the project EPIPRE (123) on supervised control of diseases and aphids in wheat. For a time, simulation became a subject of violent discussion between the pros and cons. At the close of the twentieth century, we focused on the complementarity of analytical and numerical approaches in epidemiology.
Toward the year 2000, the enthusiasm for simulation clearly diminished among plant pathologists, which is amazing in view of the problem-solving power of the technique $(6,80)$. Simulation allows intricate combinatorics such as the integration of crop ecology, pathogen ecology, and human action in an overall picture of sometimes amazing precision as regards injury and damage (5). In the process of changing present high external input agriculture into more sustainable agriculture, dynamic simulation in combination with other computer techniques is highly supportive because it presents farmers with various alternatives (84).

\section{Post-Vanderplankian Controversies}

My eclectic survey of controversies in epidemiology is not exhaustive (see 108 for a more balanced overview). Nor did I do justice to epidemiologists other than Vanderplank. The publication of several textbooks (Sidebar 2) on epidemiology after the Vanderplankian era shows that the discipline is alive and kicking. Fortunately, I see several controversies emerging that need resolving. Moving from the proximate to the ultimate I mention three.

Controversy one: running or dispersive waves. van den Bosch et al. (97) and others elaborated the theorem of the running wave of expanding foci. The theorem implies that a focal epidemic, once it gains force, expands at a constant rate, whether the epidemic is a one-season one-meter

\section{RESISTANCE}

\section{MARITTA}

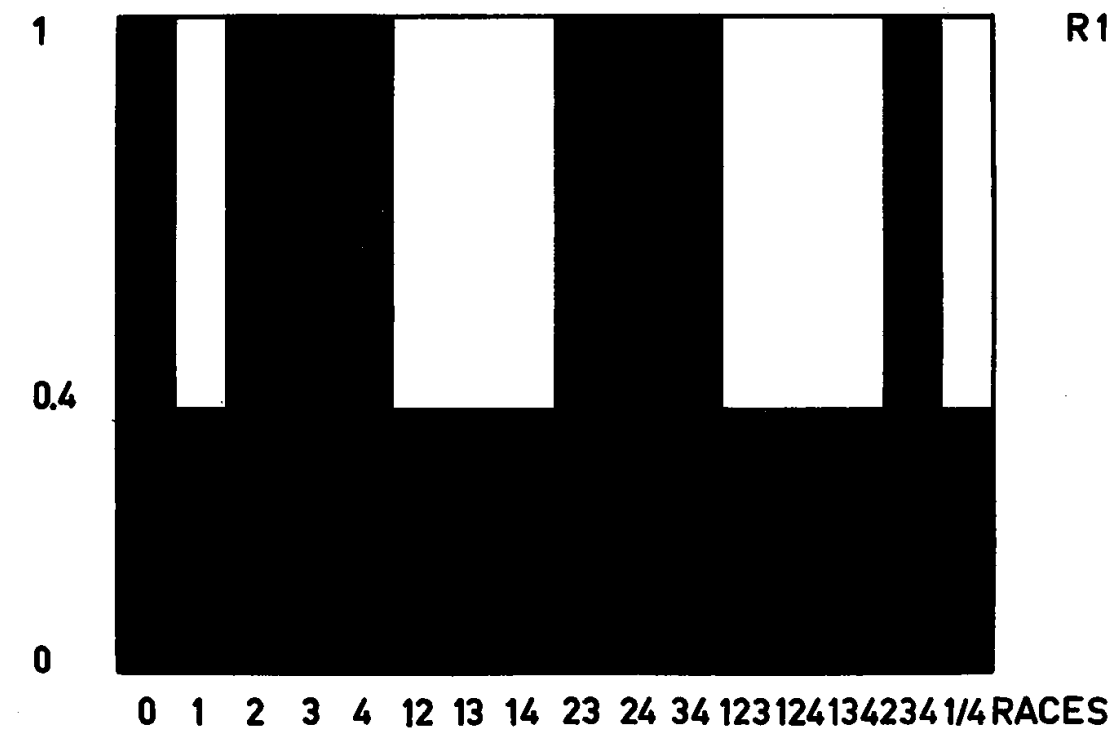

Fig. 6. Resistance of cultivar Maritta to Phytophthora infestans. Along the horizontal axis are races with virulence genes in climbing order of complexity. On the vertical axis is resistance as a figure between 0 and 1.0 . Maritta has $100 \%$ resistance to all races not containing virulence gene 1 . Columns thus represent vertical resistance and susceptibility. If the races contain virulence gene 1 , and the corresponding resistance is "broken," a moderate level (resistance $=0.4$ ) of horizontal resistance becomes visible. The two types of resistance have different genetic backgrounds and may concur in one cultivar (redrawn after 102). affair, a focus, or a pandemic spreading over a continent in a number of years of an epidemic spreads at an ever increasing rate. The two views seem to be mutually exclusive. Nevertheless, both views are py empirical data. Either view finds mathematical support (vide 21), and A final decision in this controversy not yet possible, but a first step has been made. A mathematical technique allows us theor (37). If such a distinction can be made, the next step would be to determine the "domain of validity" of either theorem. This cal thinking and experimentation.

For applications such as outlining a Fiological control of pests and epidemics is dearly needed. Similarly, the practice of quarantine and containment may find support in the theory. Here, we the technical-scientific discuspolitical implications.

Controversy two: crop loss assessment. Influential forerunners of epidemiology were recruited to solve phytopawich serious sociowas hired to solve the coffee rust problem in Ceylon. Scientifically he made great strides, but he could not prevent the abandonment of coffee cultivation and bank- 
ruptcy of growers and banks (60). Before World War I, crop loss was the international theme that led to the foundation of the International Agricultural Institute in Rome, 1905, the predecessor of FAO (126). During the interbellum, several authors showed an interest in the economic, social, and political dimensions of plant pathology. After 1945, recruitment of plant pathologists followed the intricacies of the academic world rather than economic necessities. The result was a loss of

\section{Sidebar 1. Explanation of some epidemiological concepts}

Differential interaction - Whereas in one variety resistance is high against one and low against another isolate of the pathogen, another variety shows the inverse pattern; usually based on gene-for-gene interaction.

Focus - The site of local concentrations of diseased plants or disease lesions, here about a primary source of infection.

Infection rate, exponential - Proportionality constant with dimension $\mathrm{t}^{-1}$ in equation for exponential growth.

Infection rate, logistic - Proportionality constant with dimension $\mathrm{t}^{-1}$ in equation for logistic growth.

Infection rate, corrected basic - Proportionality constant with dimension $\mathrm{t}^{-1}$ in equation for logistic growth corrected for latent period and infectious period.

Resistance, horizontal - Resistance of a variety supposedly equal to all isolates of a pathogen; no gene-for-gene interaction; resistance may be at any level from nearly zero to complete. Resistance, intermediate - Resistance, either horizontal or vertical, which is incomplete, with a level somewhere between zero and complete resistance.

Resistance, partial - An intermediate resistance due to a reduction in the number of lesions, which are of normal (susceptible) type and size.

Resistance, vertical - Single-gene resistance against pathogen with corresponding virulence gene, according to a gene-for-gene interaction.

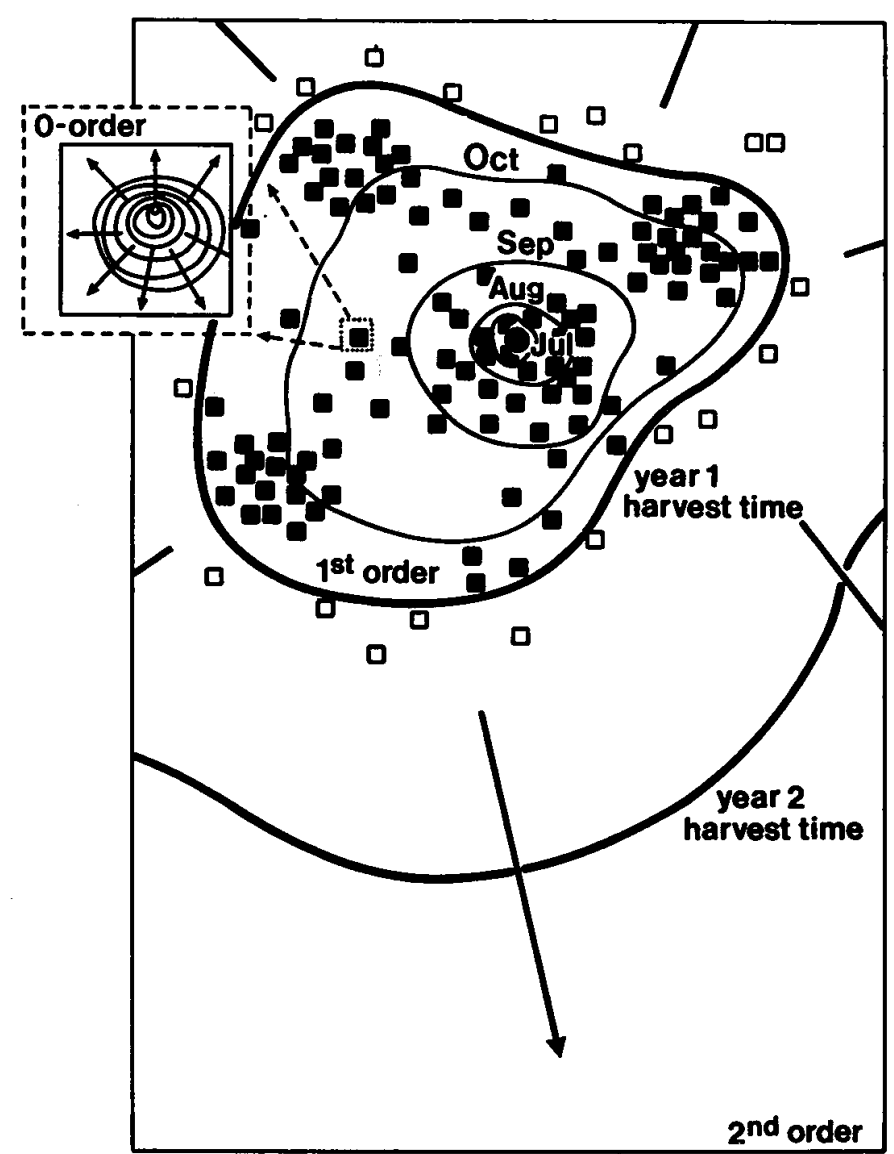

Fig. 7. Three orders of focal epidemics, schematically. At the center, the 0 -order epidemic (microlevel) or focus, enlarged in the inset, developing within one season. Successive lines of equal severity (isopaths) are drawn. Size: one to a few meters in diameter. Black squares within the inner heavy line show the results of the first-order epidemic, developing within one season (meso-level), with two thin isopaths. Size: 1 to $1,000 \mathrm{~km}$. Open squares between the two heavy lines represent the early results of the second-order epidemic (continental level), developing over successive years. (Shown is beginning of year 2 only.) Size: up to a whole continent. Original figure.

interest in solving problems in the field (44).

In 1967, FAO organized a conference on crop loss in Rome (35). Quantification of worldwide crop losses was presented by Cramer (19) and applauded. New methodology for crop loss assessment was developed (15). The enthusiasm it generated (16) was a straw fire that, briefly rekindled by a few workshops (94), gradually died down. The topic did not have the glamour of biochemistry, let alone biotechnology.

My objections to the results of Cramer and of his successor Oerke et al. (69) are of three kinds (129). First, their results were largely based on chemical control experiments, comparing well-sprayed plots to nonsprayed controls, both positioned in a well-sprayed environment where natural, biological control was practically eliminated. Hence, the environment was illchosen. Second, no alternatives other than chemical treatment were considered, such as resistance breeding or biological control. Thus, the comparisons were false. Third, the losses attributed to the individual pests were combined to give one total loss figure. Such a figure will be exaggerated because not all pests concur on the same place at the same time and because pests that do concur may interact (127: ch. $8)$. Thus, the calculations were incorrect.

New methodology for large-scale surveys (85) was proposed using individual fields (or plots) as the research units and their agricultural and phytopathological variates as the attributes. Applying nonparametric statistics, a powerful tool was created with descriptive and explanatory value at the regional level, i.e., over hundreds to thousands of kilometers. With this methodology, the International Rice Research Institute (IRRI) at Los Baños, Philippines, analyzed rice cropping patterns, pest profiles, and crop loss $(86,87)$. Scientists sampled hundreds of fields scattered over Southeast Asia. In the supporting experiments, they took care to avoid pesticide-induced changes in crop development and pesticide-induced damage to biological control. Two points became obvious: first, that severe outbreaks of pests and diseases are rare, and second, that pests interact, usually in such a way that the actual damage in farmers' fields is less than expected by adding up the damages attributed to the individual pests in those fields.

Controversy three: socioeconomic impact of epidemiology. Spanning the twentieth century once more, I come to my last controversy-or is it a self-criticism? At the beginning of the century, individuals such as Henry Marshall Ward and Jakob Eriksson (not to mention several others) were scientists with a keen eye for the socioeconomic consequences of plant disease epidemics. The young E. C. Stakman chose to study plant pathology because it was a science and it served people; he remained true to his choice and he became 
a "statesman of science" (17). Many textbooks before $(3,93)$ but few after $(91,95)$ World War II discussed socioeconomic aspects of epidemics in any depth.

Every nation has the right to choose the agriculture and the crop protection it wants, positioning itself somewhere along the line connecting organic agriculture at one end and high external input agriculture at the other. The latter engenders great social costs because of the high amounts of fertilizers and pesticides used $(70,78,111)$, and the first might not be able to feed everybody. In the year 2000, the worldwide tendency toward sustainability requires redesigning crop protection, as painfully evidenced by the recent wheat scab catastrophe in the northern great plains of North America (120). Epidemiologists can go ahead, working hand-in-hand with crop scientists and with social scientists. What combination of crop control practices will approach the social optimum, considering farm income as well as consumer prices, environmental and human health, shortterm as well as intergenerational effects, local and distant effects (129)? Transition from one way of growing crops to another may be painful, risky, and costly $(33,34)$. Institutional constraints to change are one reason (112). Another reason may be that farmers get trapped by an economic mechanism called "path dependence" (18). It implies that a farmer will experience great difficulties and/or costs in changing from one disease control policy, e.g., intensive use of pesticides, to another one, e.g., Integrated Pest Management. On-farm experimentation, preferably by farmers (14), will be needed so that epidemiologists can return to where they began, the field. New field experience is needed, and models will help to understand and predict, to extrapolate and to steer the experimentation (124).

We may learn from the sociologists. Sociologists found that different management styles may all lead to a decent farm income, with higher or with lower inputs $(90,104)$. Sociologists can also help to transit from one state of agriculture to another, more sustainable one. In parts of Southeast Asia and of Africa, Integrated Pest Management is passing the borderline between the natural and the social sciences, and is becoming applied social science $(52,107)$.

Twentieth century epidemiology began in the field; it became strong in mathematical analysis but weak in agronomic wisdom, and less than weak in socioeconomic synthesis. The potential is there, but I have not yet seen, with the exception of Nagarajan et al. (66), the right frame of mind, the right attitude to bridge a long period, a wide distance, an astonishing agrobiodiversity, a socioeconomic perspective, and eventually, political implications. This is the criticism I offer; this is the challenge I present.

Sidebar 2. Textbooks on plant disease epidemiology (nonexhaustive overview)

\begin{tabular}{lllc}
\hline Year & Authors/editors & Country & B/C/P \\
\hline 1901 & Ward (114) & UK & C \\
1946 & Gäumann (41) & Switzerland & C \\
1960 & Horsfall \& Dimond (46) & USA et al. & B \\
1963 & Vanderplank (100) & South Africa & B \\
1973 & Prasad et al. (79) & India et al. & P \\
1974 & Kranz (57) & Germany et al. & B \\
1976 & Robinson (82) & UK & B \\
1978 & Scott \& Bainbridge (88) & UK & B \\
1978 & Horsfall \& Cowling (45) & USA et al. & B \\
1979 & Zadoks \& Schein (127) & Netherlands, USA & B \\
1980 & Palti \& Kranz (71) & Germany et al. & P \\
1983 & Nagarajan (64) & India & B \\
1986 & Zeng Shimai (130) & China & B \\
1986 & Leonard \& Fry (61) & USA et al. & B \\
1988 & Kranz \& Rotem (58) & Germany et al. & B \\
1989 & Jeger (50) & UK et al. & B \\
1990 & Campbell \& Madden (12) & USA & B \\
1991 & Rapilly (81) & France & B \\
1994 & Campbell \& Benson (11) & USA et al. & B \\
1995 & Nagarajan \& Muralidharan (65) & India & B \\
1996 & Bergamin \& Amorim (6) & Brazil & B \\
1998 & Gareth Jones (40) & UK et al. & B \\
\hline B $=$ book, C Chapter, P = proceedings. & & \\
& & & \\
\hline
\end{tabular}

\section{Epilogue}

I tried to give a bird's-eye view of plant disease epidemiology as it developed into a discipline of its own during the twentieth century, developing its own language and finding support in mathematics. I indicated how forerunners of epidemiology discussed epidemiological questions, beginning with Eriksson and Marshall Ward around 1900, how Vanderplank really established the discipline as a consistent body of knowledge with predictive capacity, and how matters developed in the postVanderplankian period. I indicated what epidemiology left undone toward the end of the twentieth century. Limitations of time and of experience compelled me to make choices, personal choices. I could not discuss soilborne diseases, virus diseases, or diseases of perennial crops. Nonetheless, I attempted to give a balanced overview covering a century by focusing on selected controversies, open or hidden. I feel privileged by having participated during the second half of the twentieth century, and I am grateful for the invitation to report on that past century. The new century will provide wonderful new challenges to deepen and widen the discipline of plant disease epidemiology.

\section{Acknowledgments}

Soumaila Sanogo, then chair of the APS Standing Committee on Epidemiology, invited me to read a paper on the history of epidemiology in the twentieth century at the 2000 APS Annual Meeting, New Orleans, and so presented me with an enjoyable challenge. Carla S. Thomas, stand-in chair of the epidemiology session and excellent hostess, encouraged me to submit the paper for publication. The American Phytopathological Society covered costs of travel to and subsistence at New Orleans. Feature editors and referees of Plant Disease made valuable suggestions.

\section{Literature Cited}

1. Andow, D. A. 1999. Spread of invading organisms. Pages 66-77 in: Biological Invasions of Ecosystem by Pests and Beneficial Organisms. E. Yano, K. Matsuo, M. Shiyomi, and D. A. Andow, eds. NIAES, Tsukuba, Japan.

2. Anikster, Y. 1984. The Formae Speciales. Pages 115-130 in: The Cereal Rusts, Vol. I W. R. Bushnell and A. P. Roelfs, eds. Academic Press, Orlando, FL.

3. Arthur, J. C. 1929. The Plant Rusts (Uredinales). John Wiley \& Sons, New York.

4. Bakker, K. 1985. Algemene inleiding (General introduction). Pages 1-24 in: Inleiding tot de Oecologie (Introduction to Ecology). K. Bakker et al., eds. Bohn, Utrecht, Netherlands.

5. Bastiaans, L. 1993. Understanding yield reduction in rice due to leaf blast. Ph.D. thesis. Wageningen University, Wageningen, Netherlands.

6. Bergamin Filho, A., and Amorim, L. 1996. Doenças de plantas tropicais: Epidemiologia e controle econômico. Ceres, São Paolo, Brazil.

7. Biffen, R. H. 1905. Mendel's law of inheritance and wheat breeding. J. Agric. Sci. 1:448.

8. Bos, L. 1981. Hundred years of Koch's postulates and the history of etiology in plant virus research. Neth. J. Plant Pathol. 87:91-109.

9. Brierley, W. B. 1930. Review: Fungous diseases of plants in agriculture, horticulture and forestry. By Jacob Eriksson. Ann. Appl. Biol. 17:809-881

10. Brooks, F. T. 1953. Plant Diseases. 2nd ed Oxford University Press, London.

11. Campbell, C. L., and Benson, D. M., eds. 1994. Epidemiology and management of root diseases. Springer-Verlag, Berlin.

12. Campbell, C. L., and Madden, L. V. 1990. Introduction to Plant Disease Epidemiology. John Wiley \& Sons, New York.

13. Campbell, C. L., Peterson, P. D., and Griffith, C. S. 1999. The formative years of plant pathology in the United States. American Phytopathological Society, St. Paul, MN.

14. Chambers, R., Pacey, A., and Thrupp, L. A 
1989. Farmer first. Farmer innovation and agricultural research. Intermediate Technology Publications, London.

15. Chiarappa, L., ed. 1971. Crop loss assessment methods. FAO manual on the evaluation and prevention of losses by pests, diseases and weeds. Commonwealth Agric. Bureaux, Farnham Royal, UK.

16. Chiarappa, L., and Gonzàles, R. H. 1975. The status and requirements of the FAO International Collaborative Programme on Crop Loss Appraisal. FAO Plant Prot. Bull. 23:118-124.

17. Christensen, C. M. 1984. E. C. Stakman, statesman of science. American Phytopathological Society, St. Paul, MN.

18. Cowan, R., and Gunby, P. 1996. Sprayed to death: Path dependence, lock-in and pest control strategies. Econ. J. 106:521-542.

19. Cramer, H. H. 1967. Plant protection and world crop production. PflanzenschutzNachr. "Bayer" 20:1-524.

20. De Bary, M. A. 1863. Recherches sur le développement de quelques champignons parasites. Mémoire pour servir de réponse à une question proposée par l'Académie des Sciences en 1861 et pour servir de supplément aux travaux sur la question des générations dites spontanées. Ann. Sci. Naturelles. Partie Botanique. 4me Série, 20:5-148.

21. Dieckmann, U., Law, R., and Metz, J. A. J., eds. 2000. The geometry of ecological interactions: Simplifying spatial complexity. Cambridge studies in adaptive dynamics. Cambridge University Press, Cambridge.

22. Duggar, B. M. 1909. Fungus Diseases of Plants. Ginn, Boston.

23. Egerton, F. N. 1968. Leeuwenhoek as a founder of animal demography. J. Hist. Biol. 1:1-22.

24. Eriksson, J. 1897. Vie latente et plasmatique de certaines urédinées. CR Acad. Sci. pp. 475-477.

25. Eriksson, J. 1901/2. Sur l'origine et la propagation de la rouille des céréales par la semence. Ann. Sci. Naturelles, 8me Série, Botanique 14:1-124/15:1-160.

26. Eriksson, J. 1903. Sur l'appareil végétatif de la rouille jaune des céréales. CR Acad. Sci. 137:578-580.

27. Eriksson, J. 1903. The researches of Professor H. Marshall Ward on the brown rust on the bromes and the mycoplasm hypothesis. Arkiv Bot. 1:139-146.

28. Eriksson, J. 1910. Über die Mykoplasmatheorie, ihre Geschichte und ihren Tagesstand. Biol. Zentbl. 30:618-623.

29. Erikkson, J. 1910. F. Zach's cytologische Untersuchungen über die Rostflecken des Getreides - und die Mycoplasmatheorie. Sitzungsber. Kaiserlichen Akad. Wiss. Wien. Math.-Natwiss. Kl. 119:1043-1050.

30. Eriksson, J. 1911. Der Malvenrost (Puccinia malvacearum Mont.), seine Verbreitung, Natur und Entwicklungsgeschichte. K. Sven. Vetenskapsakad. Handlingar 47(2):1-125.

31. Eriksson, J. 1915. International phytopathological collaboration. Phytopathology 5:133-138.

32. Eriksson, J., and Henning, F. 1896. Die Getreideroste, Ihre Geschichte und Natur sowie Massregeln gegen dieselben. Meddelanden från Landtbruks-Akademiens Experimentalfålt \#38. Norstedt \& Söner, Stockholm.

33. Eshuis, J., and Buurma, J. 1998. Biologische landbouw in de Wieringermeer. (Organic Agriculture in the Wieringermeer). LEI-DLO, Meded. 619:61 pp.

34. Eshuis, J., and Buurma, J. 2000. Kennisbehoefte bij omschakeling naar geïntegreerde bollenteelt in de Kop van Noord-Holland. (Knowledge requirements for the transition to integrated flower bulb cultivation in upper North Holland). LEI, Den Haag, Report 1.00.01.

35. FAO. 1967. Papers presented at the FAO Symposium on crop losses. FAO, Rome.

36. Ferrandino, F. J. 1993. Dispersive epidemic waves: I. Focus expansion within a linear planting. Phytopathology 83:795-802.

37. Frantzen, J., and van den Bosch, F. 2000. Spread of organisms: Can travelling waves and dispersive waves be distinguished? Basic Appl. Ecol. 1:83-91.

38. Freeman, E. M. 1902. Experiments on the brown rust of bromes (Puccinia dispersa). Ann. Bot. 16:487-494

39. Freeman, E. M. 1913. Harry Marshall Ward (1854-1906). Phytopathology 3:1-2.

40. Gareth Jones, D., ed. 1998. The Epidemiology of Plant Diseases. Kluwer, Dordrecht, Netherlands.

41. Gäumann, E. 1946. Pflanzliche Infektionslehre. Birkhäuser, Basel.

42. Gilligan, C. A., ed. 1985. Mathematical modelling of crop disease. Advances Plant Pathol. 3. Academic Press, London.

43. Hirst, J. M. 1964. Fungal epidemics of plants. Nature 201:139-140.

44. Horsfall, J. G. 1969. Relevance: Are we smart outside? Phytopathol. News 3:5-9.

45. Horsfall, J. G., and Cowling, E. B., eds. 1978. Plant disease, an advanced treatise. Vol. III. How disease develops in populations. Academic Press, New York.

46. Horsfall, J. G., and Dimond, A. E., eds. 1960. Plant Pathology. An advanced treatise. Vol. III. The diseased population. Epidemics and control. Academic Press, New York.

47. Hungerford, C. W. 1920. Rust in seed wheat and its relation to seedling infection. J. Agric. Res. 19:257-278.

48. Jacobs, T., and Parlevliet, J. E., eds. 1993. Durability of Disease Resistance. Kluwer, Dordrecht, Netherlands.

49. Jeger, M. J. 1983. Analysing epidemics in time and space. Plant Pathol. 32:5-11.

50. Jeger, M. J., ed. 1989. Spatial components of plant disease epidemics. Prentice Hall, Englewood Cliffs, NJ.

51. Kampmeijer, P., and Zadoks, J. C. 1977. EPIMUL, a simulator of foci and epidemics in mixtures, multilines, and mosaics of resistant and susceptible plants. Simulation Monographs. Pudoc, Wageningen, Netherlands.

52. Kenmore, P. 1996. Integrated pest management in rice. Pages 76-97 in: Biotechnology and Integrated Pest Management. G. J. Persley, ed. CABI, Wallingford, England.

53. Kiyosawa, S., and Shiyomi, M. 1972. A theoretical evaluation of mixing resistant variety with susceptible variety for controlling plant disease. Ann. Phytopathol. Soc. Jpn. 38:41-51.

54. Klebahn, H. 1912. Grundzüge der allgemeine Phytopathologie. Bornträger, Berlin.

55. Koch, R. 1883. Über die Milzbrandimpfung, eine Entgegnung auf dem von Pasteur in Genf gehaltenen Vortrag. Theodor Fischer, Kassel, Germany.

56. Koch, R. 1891. Ueber Bakteriologische Forschung. Verh. $\mathrm{X}$ Int. Medicinischen Congr., Berlin, 1890. Band I. Hirschwald Verlag, Berlin. pp. 35-47.

57. Kranz, J., ed. 1974. Epidemics of Plant Diseases. Mathematical Analysis and Modeling. Springer-Verlag, Berlin.

58. Kranz, J., and Rotem, J., eds. 1988. Experimental Techniques in Plant Disease Epidemiology. Springer-Verlag, Heidelberg, Germany.

59. Lamberti, F., Waller, J. M., and van der Graaff, N. A., eds. 1983. Durable resistance in crops. Plenum Publishing, New York.
60. Large, E. C. 1940. The Advance of the Fungi. Jonathan Cape, London.

61. Leonard, K. J., and Fry, W. E. 1986. Plant Disease Epidemiology. Vol. I. Population Dynamics and Management. Macmillan Publishing, New York.

62. Mains, E. B. 1923. Notes on greenhouse culture methods used in rust investigations. Proc. Indiana Acad. Sci. 33:241-257.

63. Malthus, T. 1798. An essay on the principle of population, as it affects the future improvement of society. London, Johnson. In: The works of Thomas Robert Malthus, Vol I. E. A. Wrigley and D. Souden, eds. Pickering, London. 1986.

64. Nagarajan, S. 1983. Plant Disease Epidemiology. Oxford \& IBH, New Delhi.

65. Nagarajan, S., and Muralidharan, K. 1995. Dynamics of Plant Diseases. Allied Publishers, New Delhi.

66. Nagarajan, S., Verma, R. P. S., and Tyagi, B. S., eds. 1997. Vision 2020. Directorate of Wheat Research Perspective Plan. Directorate of Wheat Research, Karnal.

67. Nelson, R. R. 1970. Interaction of genes for pathogenicity and virulence in Trichometasphaeria turcica with different numbers of genes for vertical resistance in Zea mays. Phytopathology 60:1250-1254.

68. Nelson, R. R. 1978. Genetics of horizontal resistance to plant diseases. Annu. Rev. Phytopathol. 16:359-378.

69. Oerke, E. C., Dehne, H. W., Schönbeck, F., and Weber, A. 1994. Estimated losses in major food and cash crops. Elsevier, Amsterdam.

70. Oskam, A. J., and Vijftigschild, R. A. N., eds. 1997. Policy measures to control environmental impacts from agriculture. Workshop on pesticides. Proceedings and discussions. Dep. Agric. Economics and Policy, Wageningen, Netherlands.

71. Palti, J., and Kranz, J., eds. 1980. Comparative Epidemiology. A Tool for Better Disease Management. Pudoc, Wageningen, Netherlands.

72. Parlevliet, J. E. 1976. Evaluation of the concept of horizontal resistance in the barley/Puccinia hordei host-pathogen relationship. Phytopathology 66:494-497.

73. Parlevliet, J. E. 1979. Components of resistance that reduce the rate of epidemic development. Annu. Rev. Phytopathol. 17:203222.

74. Parlevliet, J. E., and Zadoks, J. C. 1977. The integrated concept of disease resistance; new view including horizontal and vertical resistance of plants. Euphytica 26:5-21.

75. Pasteur, L. 1860. Expériences relatives aux générations dites spontanées. CR hebd. Séanc. Acad. Sci. Paris. pp. 303-307.

76. Pearl, R., and Reed, L. J. 1920. On the rate of growth of the population of the United States since 1790 and its mathematical representation. Proc. Nat. Acad. Sci. 6:275-288.

77. Pieschel, E. 1931. Erfahrungen über Einsporimpfungen mit Getreiderostpilzen. Phytopathol. Z. 3:89-100.

78. Pimentel, D., Acquay, H., Biltonen, M., Rice, P., Silva, M., Nelson, J., Lipner, V. Giordano, S., Horowitz, A., and D'Amore, M. 1993. Assessment of environmental and economic impacts of pesticide use. Pages 4784 in: The Pesticide Question - Environment, Economics, and Ethics. D. Pimentel and $\mathrm{H}$ Lehman, eds. Chapman \& Hill, New York.

79. Prasad, M. R. N., Nakhasi, M. L., and Janak Raj, eds. 1973. Symposium on epidemiology, forecasting and control of plant diseases. Ind. Nat. Sci. Acad. Bull. 46.

80. Rabbinge, R., Ward, S. A., and van Laar, H. H., eds. 1989. Simulation and Systems Management in Crop Protection. Pudoc, Wagen- 
ingen, Netherlands.

81. Rapilly, F. 1991. L'épidémiologie en pathologie végétale. Mycoses aériennes. INRA, Paris.

82. Robinson, R. A. 1976. Plant Pathosystems. Springer-Verlag, Berlin.

83. Robinson, R. A., and Chiarappa, L. 1977. The International Program on Horizontal Resistance. FAO Plant Prot. Bull. 25:197-200.

84. Rossing, W. A. H., Jansma, J. E., de Ruijter, F. J., and Schans, J. 1997. Operationalizing sustainability: Exploring options for environmentally friendly flower bulb production systems. Eur. J. Plant Pathol. 103:217-234.

85. Savary, S. 1986. Études épidémiologiques sur la rouille de l'arachide en Côte d'Ivoire. $\mathrm{Ph} . \mathrm{D}$. thesis. Wageningen University, Wageningen, Netherlands.

86. Savary, S., Willocquet, L., Elazegui, F. A., Castilla, N. P., and Teng, P. S. 2000. Rice pest constraints in tropical Asia: Quantification of yield losses due to rice pests in a range of production situations. Plant Dis. 84:357-369.

87. Savary, S., Willocquet, L., Elazegui, F. A., Teng, P. S., Du, P. V., Zhu, D., Tang, Q., Huang, S., Lin, X., Singh, H. M., and Srivastava, R. K. 2000. Rice pest constraints in tropical Asia: Characterization of injury profiles in relation to production situations. Plant Dis. 84:341-356.

88. Scott, P. R., and Bainbridge, A., eds. 1978. Plant Disease Epidemiology. Blackwell, Oxford.

89. Smith, E. F. 1905. Bacteria in Relation to Plant Diseases. Vol. I. Methods of Work and General Literature of Bacteriology Exclusive of Plant Diseases. Carnegy Institution, Washington, DC.

90. Spaan, J. H., and Van der Ploeg, J. D. 1992. Toppers en tuinders. Bedrijfsstijlen in de glastuinbouw: een verkenning. Vakgroep Agrarische Ontwikkeling LUW, Wageningen, Netherlands.

91. Stakman, E. C., and Harrar, J. G. 1957. Principles of Plant Pathology. Ronald Press, New York.

92. Stakman, E. C., Piemeisel, F. J., and Levine, M. N. 1918. Plasticity of biological forms of Puccinia graminis. J. Agric. Res., Washington 15:221-249.

93. Stevens, N. E., and Stevens, R. B. 1952. Disease in plants: An Introduction to Agricultural Phytopathology. Chronica Botanica, MA.

94. Teng, P. S., and Krupa, S. V., eds. 1980. Assessment of losses which constrain production and crop improvement in agriculture and forestry. Proc. E. C. Stakman Commemorative Sympos. Department of Plant Pathology, University of Minnesota, St. Paul.

95. Ten Houten, J. G. 1959. Scope and contributions of plant pathology. Pages 20-60 in: Plant Pathology. An Advanced Treatise. I. J. G. Horsfall and A. E. Dimond, eds. Academic Press, New York.

96. Tubajika, K. M., Russin, J. S., and Harrison, S. A. 1999. Analysis of bacterial leaf streak epidemics on winter wheat in Louisiana. Plant Dis. 83:541-548.

97. van den Bosch, F., Metz, J. A. J., and Zadoks, J. C. 1999. Pandemics of focal plant disease, a model. Phytopathology 89:495-505.

98. Vanderplank, J. E. 1949. The relation between the size of fields and the spread of plant diseases into them. Part II. Diseases caused by fungi with air-borne spores; with a note on horizons of infection. Empire J. Exp. Agric. 12:18-22.

99. Vanderplank, J. E. 1960. Analysis of epidemics. Pages 229-289 in: Plant Pathology. An Advanced Treatise. Vol. III. The Diseased
Population. Epidemics and Control. J. G. Horsfall and A. E. Dimond, eds. Academic Press, New York.

100. Vanderplank, J. E. 1963. Plant Diseases: Epidemics and Control. Academic Press, New York.

101. Van der Plank, J. E. 1967. Spread of plant pathogens in space and time. Pages 227-246 in: Airborne Microbes. P. H. Gregory and J. L. Monteith, eds. Cambridge University Press, Cambridge.

102. Van der Plank, J. E. 1968. Disease Resistance in Plants. Academic Press, New York.

103. Vanderplank, J. E. 1975. Principles of Plant Infection. Academic Press, New York.

104. Van der Ploeg, J. D., and Long, A., eds. 1994. Born from Within: Practice and Perspectives of Endogenous Rural Development. van Gorcum, Assen, Netherlands.

105. Verhulst, P. E. 1838. Notice sur la loi que la population suit dans son accroissement. Corres. Math. Phys. 10:113-121.

106. Von Tubeuf, K. 1895. Pflanzenkrankheiten durch kryptogame Parasiten verursacht. Springer-Verlag, Berlin.

107. Vos, J. 1998. Development of decisionmaking tools for vegetable farmers in Southeast Asia. Pages 404-409 in: Ecotoxicology. Pesticides and Beneficial Organisms. P. T. Haskell and P. McEwen, eds. Kluwer, Dordrecht, Netherlands.

108. Waggoner, P. E., and Aylor, D. E. 2000. Epidemiology, a science of patterns. Annu. Rev. Phytopathol. 38:71-94.

109. Waggoner, P. E., and Horsfall, J. G. 1969. EPIDEM, a simulator of plant disease written for a computer. Bull. Connecticut Agric. Exp. Stn., New Haven, No. 698.

110. Waggoner, P. E., Horsfall, J. G., and Lukens, R. J. 1972. EPIMAY, A simulator of southern corn leaf blight. Bull. Connecticut Agric. Exp. Stn., New Haven, No. 729.

111. Waibel, H., and Fleischer, G. 1998. Kosten und Nutzen des chemischen Pflanzenschutzes in der deutschen Landwirtschaft aus gesamtwirtschaftlicher Sicht. Vauk, Kiel, Germany.

112. Waibel, H., and Zadoks, J. C., eds. 1996. Institutional constraints to IPM. Pesticide Policy Project Publication Series \#3, Hannover.

113. Ward, H. M. 1882. Researches on the lifehistory of Hemileia vastatrix, the fungus of the "coffee-leaf disease." J. Linnean Soc. (Botany) 19:299-335.

114. Ward, H. M. 1901. Disease in Plants. Macmillan Publishing, London.

115. Ward, H. M. 1902. On pure cultures of a uredine, Puccinia dispersa (Erikss.). Proc. Royal Soc. London 69:451-466.

116. Ward, H. M. 1903. On the histology of Uredo dispersa, Erikss., and the "mycoplasm" hypothesis. Philos. Trans. Royal Soc., London 196:29-46.

117. Ward, H. M. 1903. Further researches on the brown rust of the bromes, Puccinia dispersa (Erikss.), and its adaptive parasitism. Ann. Mycol., Berlin 1:133-151.

118. Ward, H. M. 1904. On the histology of Uredo dispersa, Erikss., and the "Mycoplasm" hypothesis. Philos. Trans. Royal Soc. B 196:29-46.

119. Whetzel, H. H. 1918. An outline of the history of phytopathology. Saunders, Philadelphia.

120. Windels, C. E. 2000. Presidential address: Economic and social impacts of Fusarium head blight: Changing farms and rural communities in the Northern Great Plains. Phytopathology 90:17-21.

121. Zadoks, J. C. 1961. Yellow rust on wheat, studies in epidemiology and physiologic specialization. Tijdschr. Plantenziekten
67:69-256.

122. Zadoks, J. C. 1972. Modern concepts of disease resistance in cereals. Pages 89-98 in: The way ahead in plant breeding, F. G. H Lupton et al., eds. Proc. Eucarpia Congr., 6th, Cambridge, 1971.

123. Zadoks, J. C. 1989. EPIPRE, a computerbased decision support system for pest and disease control in wheat: Its development and implementation in Europe. Plant Dis. Epidemiol. 2:3-29.

124. Zadoks, J. C. 1999. Reflections on space, time and diversity. Annu. Rev. Phytopathol.

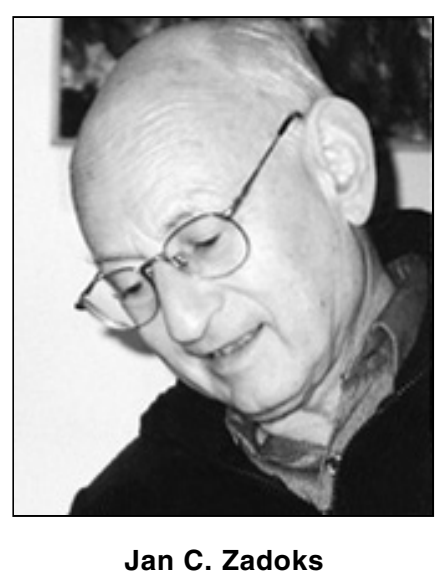

Dr. Zadoks studied biology at the University of Amsterdam, graduating in 1957. He earned his Ph.D. at the same University in 1961 with a thesis on the epidemiology of stripe rust on wheat. In 1961, Dr. Zadoks joined the Wageningen Agricultural University. He served a 3-year (1972 to 1975) term as dean. He served 3 years on the Pesticides Registration Board of The Netherlands and 10 years on the Committee on Genetic Modification of The Netherlands. He developed what was possibly the world's first practical course in plant disease epidemiology, and also courses in aerobiology, crop loss, genetics of resistance, and plant protection and society. The first course led to Zadoks and Schein's 1979 book, Epidemiology and Plant Disease Management. He initiated several (inter)national postgraduate courses on dynamic simulation in crop protection. He engaged in dynamic simulation of plant disease epidemiology and initiated the development of the computerized pest and disease warning system EPIPRE for wheat. More recently, he was involved in field studies, computer simulations, and mathematical analyses of focus formation in plant disease. Dr. Zadoks participated in several missions to review institutions in the tropics. He was a member of the FAO/UNEP Panel of Experts for Integrated Pest Control and the organizer of the 13th International Plant Protection Congress. He received the Adventurers in Agricultural Science Award of Distinction, Washington, 1979, and two Dutch Royal Awards (1980, 1994). He was elected Fellow of the American Phytopathological Society in 1994. 
37:1-17.

125. Zadoks, J. C. 2000. Foci, small and large: A specific class of biological invasions. Pages 292-317 in: The Geometry of Ecological Interactions: Simplifying Spatial Complexity. Cambridge Studies in Adaptive Dynamics. U. Dieckmann, R. Law, and J. A. J. Metz, eds. Cambridge University Press, Cambridge.

126. Zadoks, J. C., and Koster, L. M. 1976. A historical survey of botanical epidemiology. A sketch of the development of ideas in ecological phytopathology. Meded. Landbouwhogeschool, Wageningen 76-12: 1-56.

127. Zadoks, J. C., and Schein, R. D. 1979. Epidemiology and Plant Disease Management. Oxford University Press, New York.

128. Zadoks, J. C., and Schein, R. D. 1988. James Edward Vanderplank: Maverick and innova- tor. Annu. Rev. Phytopathol. 26:31-36.

129. Zadoks, J. C., and Waibel, H. 2000. From pesticides to genetically modified plants: history, economics and politics. Neth. J. Agric. Sci. 48:125-149.

130. Zeng Shimai 1986. Zhiwu Binghai Liuxingxue (Handbook of Plant Disease Epidemiology). Beijing Agricultural University Press, Beijing. 